Prepared in cooperation with the New Jersey Department of Environmental Protection

Summary of Oceanographic Measurements for Characterizing Light Attenuation and Sediment Resuspension in the Barnegat Bay-Little Egg Harbor Estuary, New Jersey, 2013
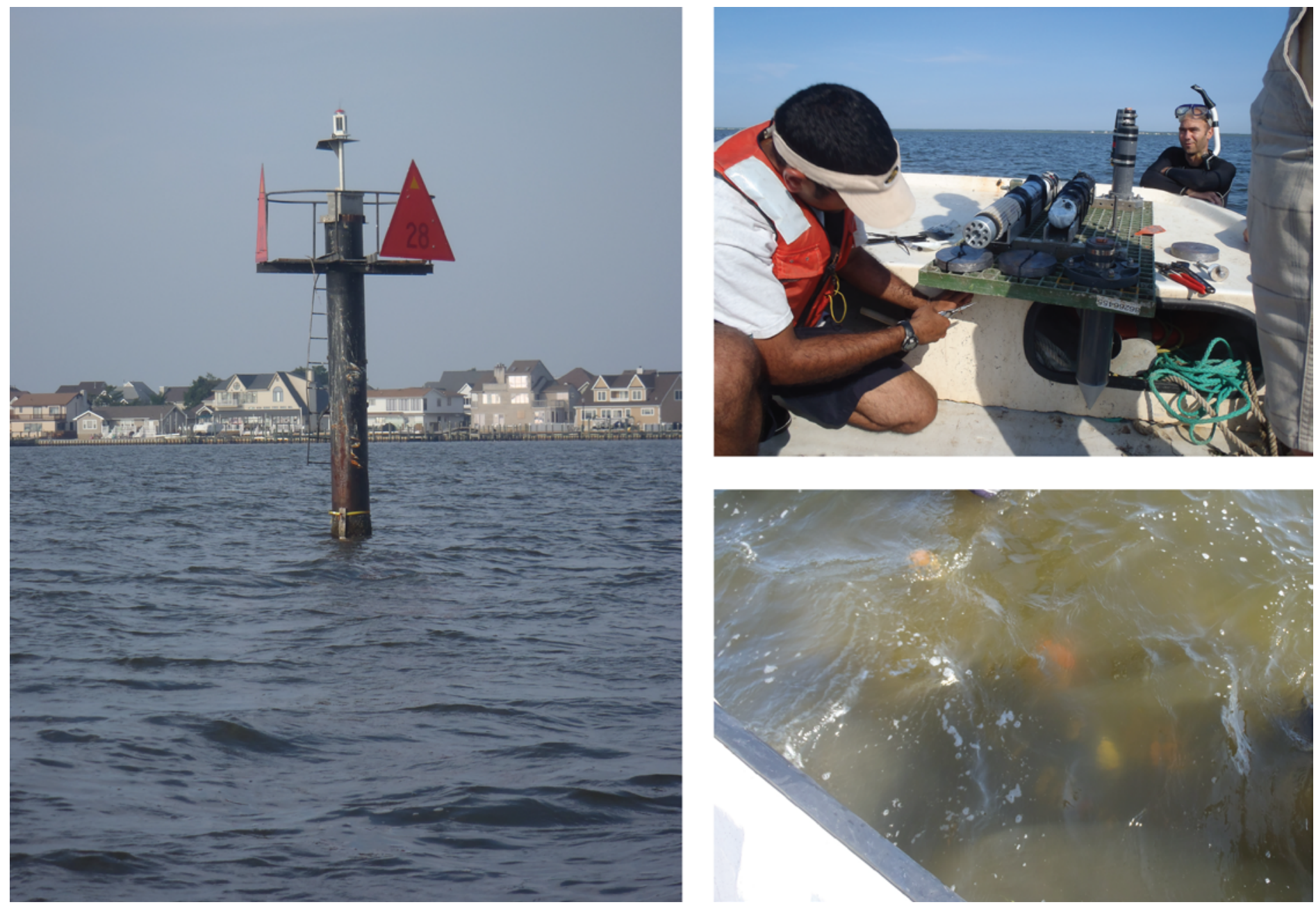

Open-File Report 2015-1146 
Cover. Left: red marker 28 in northern Barnegat Bay, New Jersey. Top right: assembly of platform prior to deployment. Bottom right: platform deployed on the bottom of the estuary in 1 meter of water in central Barnegat Bay. 


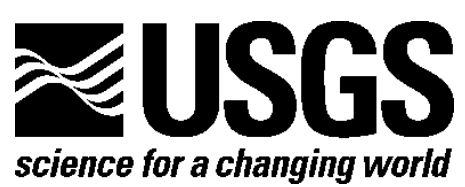

Prepared in cooperation with the New Jersey Department of Environmental Protection

\section{Summary of Oceanographic Measurements for Characterizing Light Attenuation and Sediment Resuspension in the Barnegat Bay-Little Egg Harbor Estuary, New Jersey, 2013}

By Patrick J. Dickhudt, Neil K. Ganju, and Ellyn T. Montgomery

Open-File Report 2015-1146

U.S. Department of the Interior

U.S. Geological Survey 


\section{U.S. Department of the Interior \\ SALLY JEWELL, Secretary}

\section{U.S. Geological Survey \\ Suzette M. Kimball, Acting Director}

U.S. Geological Survey, Reston, Virginia: 2015

For more information on the USGS—-the Federal source for science about the Earth, its natural and living resources, natural hazards, and the environment-visit http://www.usgs.gov/ or call 1-888-ASK-USGS (1-888-275-8747).

For an overview of USGS information products, including maps, imagery, and publications, visit http://www.usgs.gov/pubprod/.

Any use of trade, firm, or product names is for descriptive purposes only and does not imply endorsement by the U.S. Government.

Although this information product, for the most part, is in the public domain, it also may contain copyrighted materials as noted in the text. Permission to reproduce copyrighted items must be secured from the copyright owner.

Suggested citation:

Dickhudt, P.J., Ganju, N.K, and Montgomery, E.T., 2015, Summary of oceanographic measurements for characterizing light attenuation and sediment resuspension in the Barnegat Bay-Little Egg Harbor estuary, New Jersey, 2013: U.S. Geological Survey Open-File Report 2015-1146, 18 p., http://dx.doi.org/10.3133/ofr20151146.

ISSN 2331-1258 (online) 


\section{Acknowledgments}

This report was prepared with the cooperation and support of the New Jersey Department of Environmental Protection. The authors thank the members of the Rutgers University Marine Field Station for their support, especially Tom Malatesta, Roland Hagan, Rose Petrecca, and Ken Able. Field and analytical support were provided by Sandy Brosnahan, Jon Borden, Zafer Defne, Christine Sabens, and Kate McMullen, all of the U.S. Geological Survey. 


\section{Contents}

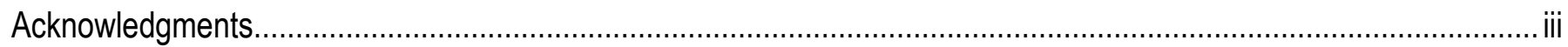

Abstract ……

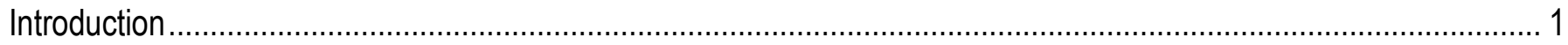

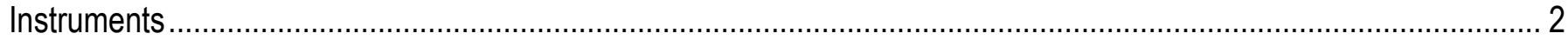

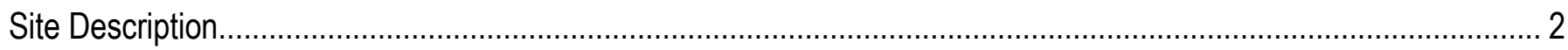

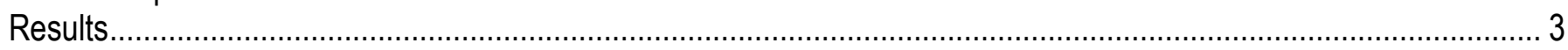

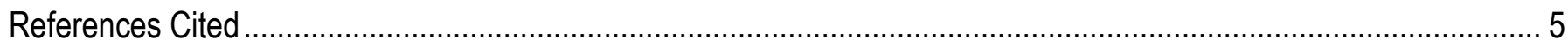

Figures

\section{Figures}

1. Maps showing sampling locations in the Barnegat Bay-Little Egg Harbor estuary, New Jersey ...................... 6

2. Photograph of the shallow water irradiance platform prior to deployment in the Barnegat Bay-Little Egg Harbor estuary, New Jersey

3. Photograph of pole-mounted sensors deployed in the Barnegat Bay-Little Egg Harbor estuary, New Jersey.. 8

4. Photograph of biological fouling on the Tices Shoal shallow water irradiance platform after recovery in the Barnegat Bay-Little Egg Harbor estuary, New Jersey.

5. Photograph of fouling on the pole-mounted sensors after recovery from Tices Shoal channel in the Barnegat Bay-Little Egg Harbor estuary, New Jersey.

6. Chart showing the data available over time, by sensor and site, in the Barnegat Bay-Little Egg Harbor estuary, New Jersey

7. Graphs showing depth, temperature, and salinity time series from YSI EXO2 deployed in the Barnegat Bay-Little Egg Harbor estuary, New Jersey.....

8. Graphs showing turbidity, chlorophyll a, and fluorescent dissolved organic matter time series from YSI EXO2 deployed in the Barnegat Bay-Little Egg Harbor estuary, New Jersey.....

9. Graphs showing oxygen percent saturation, $\mathrm{pH}$, blue-green algae, and battery voltage time series from YSI EXO2 deployed in the Barnegat Bay-Little Egg Harbor estuary, New Jersey.

10. Graphs showing photosynthetically active radiation time series from Wet Labs ECO-PARSB sensors

deployed in the Barnegat Bay-Little Egg Harbor estuary, New Jersey ……………............................... 15

11. Graphs showing temperature time series from RBR Solo T deployed in the Barnegat Bay-Little Egg Harbor estuary, New Jersey

12. Graph showing pressure time series from RBR Virtuoso D/wave deployed in the Barnegat Bay-Little Egg Harbor estuary, New Jersey.....

13. Graphs showing pressure, current speed, and current direction time series from Nortek Aquadopp HR deployed in the Barnegat Bay-Little Egg Harbor estuary, New Jersey ....

14. Graphs showing pressure time series from RBR Virtuoso D/wave and turbidity time series from Wet Labs ECO-NTUSB deployed in the Barnegat Bay-Little Egg Harbor estuary, New Jersey.. 


\section{Tables}

1. Sensor deployment and location information for platforms deployed in the Barnegat Bay-Little Egg Harbor estuary, New Jersey.....

2. Site identification number, instrument type, instrument serial number, instrument elevation, and links to the associated data files for platforms deployed in the Barnegat Bay-Little Egg Harbor estuary, New Jersey

\section{Conversion Factors}

International System of Units to Inch/Pound

\begin{tabular}{lcc}
\hline Multiply & By & To obtain \\
\hline Length & \\
\hline meter $(\mathrm{m})$ & 3.281 & foot $(\mathrm{ft})$ \\
\hline \multicolumn{3}{c}{ Area } \\
\hline square meter $\left(\mathrm{m}^{2}\right)$ & 0.0002471 & acre \\
\hline Temperature in degrees Celsius $\left({ }^{\circ} \mathrm{C}\right)$ may be converted to degrees Fahrenheit $\left({ }^{\circ} \mathrm{F}\right)$ as ${ }^{\circ} \mathrm{F}=\left(1.8 \times{ }^{\circ} \mathrm{C}\right)+32$.
\end{tabular}

\section{Supplemental Information}

Pressure measured underwater is given in decibars (dbar).

Salinity is given as practical salinity units (PSU).

Photosynthetically active radiation is given in microeinsteins per meter squared per second $\left(\mu \mathrm{E} / \mathrm{m}^{2} / \mathrm{s}\right)$.

Current speed is given in centimeters per second $(\mathrm{cm} / \mathrm{s})$. Turbidity is given as formazin nephelometric units (FNU) or nephelometric turbidity units (NTU).

Chlorophyll $a$ is given as relative fluorescence units (RFU).

Fluorescent dissolved organic matter is given as quinine sulfate units (QSU).

\section{Abbreviations}

$\begin{array}{ll}\text { EPIC } & \text { Equatorial Pacific Information Collection } \\ \text { ESA } & \text { ecologically sensitive area } \\ \text { fDOM } & \text { fluorescent dissolved organic matter } \\ \text { mab } & \text { meters above bottom } \\ \text { NetCDF } & \text { Network Common Data Form } \\ \text { PAR } & \text { photosynthetically active radiation } \\ \text { SWIP } & \text { shallow water irradiance platform } \\ \text { USGS } & \text { U.S. Geological Survey }\end{array}$




\title{
Summary of Oceanographic Measurements for Characterizing Light Attenuation and Sediment Resuspension in the Barnegat Bay-Little Egg Harbor Estuary, New Jersey, 2013
}

\author{
By Patrick J. Dickhudt, Neil K. Ganju, and Ellyn T. Montgomery
}

\begin{abstract}
The U.S. Geological Survey, in cooperation with the New Jersey Department of Environmental Protection, measured suspended-sediment concentrations, currents, waves, light attenuation, and a variety of other water-quality parameters in the summer of 2013 in Barnegat Bay-Little Egg Harbor, New Jersey. These measurements quantified light attenuation and sediment resuspension in three seagrass meadows. Data were acquired sequentially at three paired channel-shoal sites, as the equipment was moved from south to north in the estuary. Data were collected for approximately 3 weeks at each site.
\end{abstract}

\section{Introduction}

Light attenuation is a critical parameter governing the ecological function of shallow estuaries. The U.S. Geological Survey (USGS), in cooperation with the New Jersey Department of Environmental Protection, quantified light attenuation and sediment resuspension in three seagrass meadows in Barnegat Bay-Little Egg Harbor, New Jersey, by sequentially deploying a pair of instrumented platforms at each site. The seafloor platform, referred to as a shallow water irradiance platform (SWIP), measured light attenuation (by paired photosynthetically active radiation [PAR] sensors), chlorophyll- $a$ fluorescence, dissolved organic matter fluorescence (fDOM; a proxy for colored dissolved organic matter absorbance), turbidity, pressure, and water velocity at 5-minute intervals. The platform for midwater measurements of pressure and turbidity was deployed in the adjacent channel strapped to a bridge piling, or channel marker. Both platforms collected data over periods of approximately 3 weeks at each site. 


\section{Instruments}

In this experiment, autonomous instruments, with internal power and memory, were deployed at multiple sites in Barnegat Bay-Little Egg Harbor, N.J. (fig. 1). These measurements quantified light attenuation in shallow seagrass beds and measured the physical and water-quality parameters that were likely to influence light attenuation.

Two platforms were used, and the pair was moved to a new location twice during the experiment. The shallow water irradiance platform (SWIP) was a $1 \times 0.5$-meter $(\mathrm{m})$ fiberglass grate with aluminum channels equipped with sensors to measure turbidity, temperature, pressure, salinity, oxygen, $\mathrm{pH}$, chlorophyll- $a$, fluorescent dissolved organic matter, waves, currents, and light attenuation (fig. 2). At each site, this platform was deployed in a bare spot in a seagrass bed. The other platform was a pole supporting two instruments that were suspended from an existing structure in or near the channel to obtain midwater measurements of pressure and turbidity (fig. 3). Use of the pair of platforms allows comparison of suspended-sediment concentrations and wave characteristics between the main channel and the adjacent shoal.

The SWIP supported seven sensors:

- two Wet Labs ECO-PARSB self-wiping photosynthetically-active radiation (PAR of 400 to 700 nanometers) sensors mounted 0.13 and $0.44 \mathrm{~m}$ above the sea floor

- two RBR Solo T fast-response temperature recorders mounted 0.13 and $0.44 \mathrm{~m}$ above the sea floor

- a Nortek high-resolution Aquadopp HR velocity profiler

- an RBR Virtuoso D|wave fast-response pressure logger

- a YSI EXO2 water-quality sonde

The vertical separation of the two PAR and two Solo sensors allowed an estimate of light attenuation and temperature to be computed.

The pole platform supported two sensors mounted adjacent to each other:

- an RBR Virtuoso D|wave fast-response (6-hertz) pressure logger

- a Wet Labs ECO-NTUSB turbidity sensor

More information about the sensors is available at the manufacturers' Web sites. Each sensor sampled at regular intervals between 0.1667 second and 5 minutes. The SWIP platforms were deployed on the sea floor in shallow water (nominally $1-\mathrm{m}$ depth), and the pole platforms were suspended in deeper water approximately 1 to $1.5 \mathrm{~m}$ above the sea floor.

\section{Site Description}

Portions of Barnegat Bay and Little Egg Harbor are designated as ecologically sensitive areas (ESAs), and boaters are encouraged to avoid these areas to minimize damage to seagrass and benthic habitats. Nonetheless, some ESAs experience substantial recreational vessel traffic. Shoal sites were chosen to coincide with one of three archetypes: Little Egg Island was in an ESA with minimal vessel traffic, Tices Shoal was in an ESA with substantial vessel traffic, and Lavallette was not in an ESA and had substantial vessel traffic. At all three sites, we chose areas with seagrass coverage but deployed the platform on bare patches of the bed within the meadow. Bare patches were typically 10 square meters but surrounded on all sides by vegetation. The seagrass composed different species depending on 
location; northern locations are dominated by Ruppia, and central and southern locations are dominated by Zostera (Kennish and others, 2013).

Existing structures at the channel sites were used to support our sensors. The midchannel piling of the State Route 72 bridge supported the pole for the first deployment (fig. 3), red channel marker 40 supported the Tices Shoal channel site for the middle deployment, and red channel marker 28 supported the Lavallette channel site for the third deployment.

The southernmost sites, Little Egg Harbor shoal and the State Route 72 bridge, were occupied first, from June 26 to July 16, 2013. The platforms were then recovered, the data offloaded, and the instruments refurbished. The platforms were redeployed at Tices Shoal and red channel marker 40, from July 17 to August 13,2013. The process was repeated again, this time with the platforms redeployed at the northernmost sites, Lavallette shoal and red channel marker 28, from August 14 to September 12, 2013 (table 1).

Table 1. Sensor deployment and location information for mooring deployed in the Barnegat Bay-Little Egg Harbor estuary, New Jersey. [ID, identification number; N, north; W, west; m, meters; \#, number]

\begin{tabular}{clcccl}
\hline $\begin{array}{c}\text { Mooring } \\
\text { ID }\end{array}$ & \multicolumn{1}{c}{ Site name } & $\begin{array}{c}\text { Latitude } \\
(\mathbf{N})\end{array}$ & $\begin{array}{c}\text { Longitude } \\
(\mathbf{W})\end{array}$ & $\begin{array}{c}\text { Depth } \\
(\mathbf{m})\end{array}$ & \multicolumn{1}{c}{ Deployment period } \\
\hline 961 & Little Egg Island Shoal & 39.63156 & 74.21864 & 0.8 & June 26, 2013-July 16, 2013 \\
962 & State Route 72 bridge & 39.84426 & 74.09628 & 2 & June 26, 2013-July 16, 2013 \\
963 & Tices Shoal & 39.63156 & 74.21864 & 0.8 & July 17, 2013-August 13, 2013 \\
964 & Red channel marker \#40 & 39.86173 & 74.12253 & 2.5 & July 17, 2013-August 13, 2013 \\
977 & Lavallette Shoal & 39.95982 & 74.09451 & 0.6 & August 14, 2013-September 12, 2013 \\
978 & Red channel marker \#28 & 39.96017 & 74.10470 & 2.5 & August 14, 2013-September 12, 2013 \\
\hline
\end{tabular}

\section{Results}

Water-quality and current-velocity data were collected at three pairs of sites in Barnegat Bay, N.J., from June 26, 2013, to September 12, 2013. Although there was biofouling of instruments (figs. 4 and 5), it did not degrade the data because the deployments were short and all instruments were either equipped with antifouling measures (wipers, copper coatings, zinc oxide paste) or were highly resistant to fouling. Overall data return was high with the exception of a few instrument failures (fig. 6).

Figures 7, 8, and 9 present the data from the YSI EXO2. The results from the two Wet Labs ECO-PARSBs are shown in figure 10. The temperature time series from the two RBR Solo T sensors are shown in figure 11. The pressure time series from the RBR D|wave is shown in figure 12 . The pressure, current speed, and direction time series from the Nortek Aquadopp HR is shown in figure 13. The pressure time series from the RBR D|wave and the turbidity time series from the Wet Labs ECONTUSB are shown in figure 14 (table 2). 
Table 2. Site identification number, instrument type, instrument serial number, instrument elevation, and links to the associated data files for platforms deployed in the Barnegat Bay-Little Egg Harbor estuary, New Jersey.

[ID, identification number; no., number]

\begin{tabular}{|c|c|c|c|c|}
\hline $\begin{array}{l}\text { Mooring } \\
\text { ID }\end{array}$ & Instrument & Serial no. & $\begin{array}{c}\text { Sensor elevation } \\
\text { (meters above bottom) }\end{array}$ & Data file \\
\hline \multicolumn{5}{|c|}{ 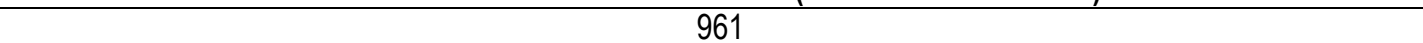 } \\
\hline 9611 & Wet Labs ECO-PARSB & 274 & 0.44 & 9611 ecp-a.nc \\
\hline 9612 & RBR Solo T & 75565 & 0.44 & 9612solot-a.nc \\
\hline 9613 & Nortek Aquadopp HR & 5373 & 0.17 & 9613HRaqd-cal.nc \\
\hline 9614 & RBR D|wave & 55023 & 0.17 & 9614dw-a.nc \\
\hline 9615 & YSI EXO2 & $13 \mathrm{E} 103375$ & 0.15 & 9615exo-a.nc \\
\hline 9616 & Wet Labs ECO-PARSB & 273 & 0.13 & 9616еcp-a.nc \\
\hline 9617 & RBR Solo T & 75563 & 0.13 & 9617solot-a.nc \\
\hline \multicolumn{5}{|c|}{962} \\
\hline 9621 & RBR D|wave & 55025 & ${ }^{1} 1.1$ & 9621dw-a.nc \\
\hline 9622 & Wet Labs ECO-NTUSB & 508 & ${ }^{1} 1.22$ & 9622 ecn-a.nc \\
\hline \multicolumn{5}{|c|}{ 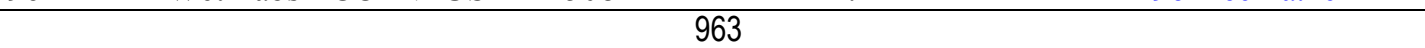 } \\
\hline 9631 & Wet Labs ECO-PARSB & 274 & 0.44 & 9631 ecp-a.nc \\
\hline 9632 & RBR Solo T & 75565 & 0.44 & 9632solot-a.nc \\
\hline 9633 & Nortek Aquadopp HR & 5373 & 0.17 & 9633HRaqd-cal.nc \\
\hline 9634 & RBR D|wave & 55023 & 0.17 & 9634dw-a.nc \\
\hline 9635 & YSI EXO2 & $13 \mathrm{E} 103375$ & 0.15 & 9635exo-a.nc \\
\hline 9636 & Wet Labs ECO-PARSB & 273 & 0.13 & 9636еep-a.nc \\
\hline 9637 & RBR Solo T & 75563 & 0.13 & 9637solot-a.nc \\
\hline \multicolumn{5}{|c|}{964} \\
\hline 9641 & RBR D|wave & 55025 & ${ }^{1} 1.6$ & 9641dw-a.nc \\
\hline 9642 & Wet Labs ECO-NTUSB & 508 & ${ }^{1} 1.72$ & 9642ecn-a.nc \\
\hline \multicolumn{5}{|c|}{977} \\
\hline 9771 & Wet Labs ECO-PARSB & 274 & 0.44 & 9771 ecp-a.nc \\
\hline 9772 & RBR Solo T & 75565 & 0.44 & 9772solot-a.nc \\
\hline 9773 & Nortek Aquadopp HR & 5373 & 0.17 & 9773HRaqds-cal.no \\
\hline 9774 & RBR D|wave & 55023 & 0.17 & 9774dw-a.nc \\
\hline 9775 & YSI EXO2 & $13 \mathrm{E} 103375$ & 0.15 & 9775exo-a.nc \\
\hline 9776 & Wet Labs ECO-PARSB & 366 & 0.13 & 9776ecp-a.nc \\
\hline 9777 & RBR Solo T & 75563 & 0.13 & 9777solot-a.nc \\
\hline \multicolumn{5}{|c|}{978} \\
\hline 9781 & RBR D|wave & 55025 & ${ }^{1} 1.6$ & 9781dw-a.nc \\
\hline 9782 & Wet Labs ECO-NTUSB & 508 & ${ }^{1} 1.72$ & 9782ecn-a.nc \\
\hline
\end{tabular}

${ }^{1}$ Elevation of pole-mounted sensors is approximate and estimated from pressure record and water depth.

The data from all instruments were stored internally. After each recovery, the manufacturers' software was used to download the data, apply calibration coefficients, and convert the data to scientific units. These output files were then converted by custom, instrument-specific Matlab programs to Equatorial Pacific Information Collection (EPIC) convention-compliant Network Common Data Form (NetCDF) files for distribution on the USGS sediment transport data distribution Web site. Files listed in this report are linked to their locations on the distribution site from which they may be downloaded. Additional information on data processing, quality assurance and control protocols, file formats, nomenclature, and access methods used is provided in Montgomery and others (2008).

The landing page for the data (Dickhudt and others, 2015) contains details of all field activities associated with this project, Google Earth visualizations of deployment locations, and sampling interval information. The edited, final data can be downloaded or accessed directly by using OPeNDAP at the 
"Data access via THREDDS" link on the landing page. File naming conventions for time-series observations are described in the "File Naming Conventions" section of Montgomery and others (2008).

\section{References Cited}

Dickhudt, P.J., Ganju, N.K., Montgomery, E.T., and Martini, M.A., 2015, Oceanographic measurements for characterizing light attenuation and sediment resuspension in the Barnegat Bay-Little Egg Harbor estuary, New Jersey, 2013: U.S. Geological Survey data release, accessed May 20, 2015, at http://dx.doi.org/10.5066/F7GB224S.

Kennish, M.J., Fertig, B.M., and Sakowicz, G.P., 2013, In situ surveys of seagrass habitat in the northern segment of the Barnegat Bay-Little Egg Harbor estuary-Eutrophication assessment: Barnegat Bay Partnership Web site, accessed May 18, 2015, at http://bbp.ocean.edu/Reports/2011\%20Northern\%20seagrass\%20survey.pdf.

Montgomery, E.T., Martini, M.A., Lightsom, F.L. and Butman, Bradford, 2008, Documentation of the U.S. Geological Survey oceanographic time series measurement database: U.S. Geological Survey Open-File Report 2007-1194, accessed March 14, 2015, at http://pubs.usgs.gov/of/2007/1194/. 


\section{Figures}

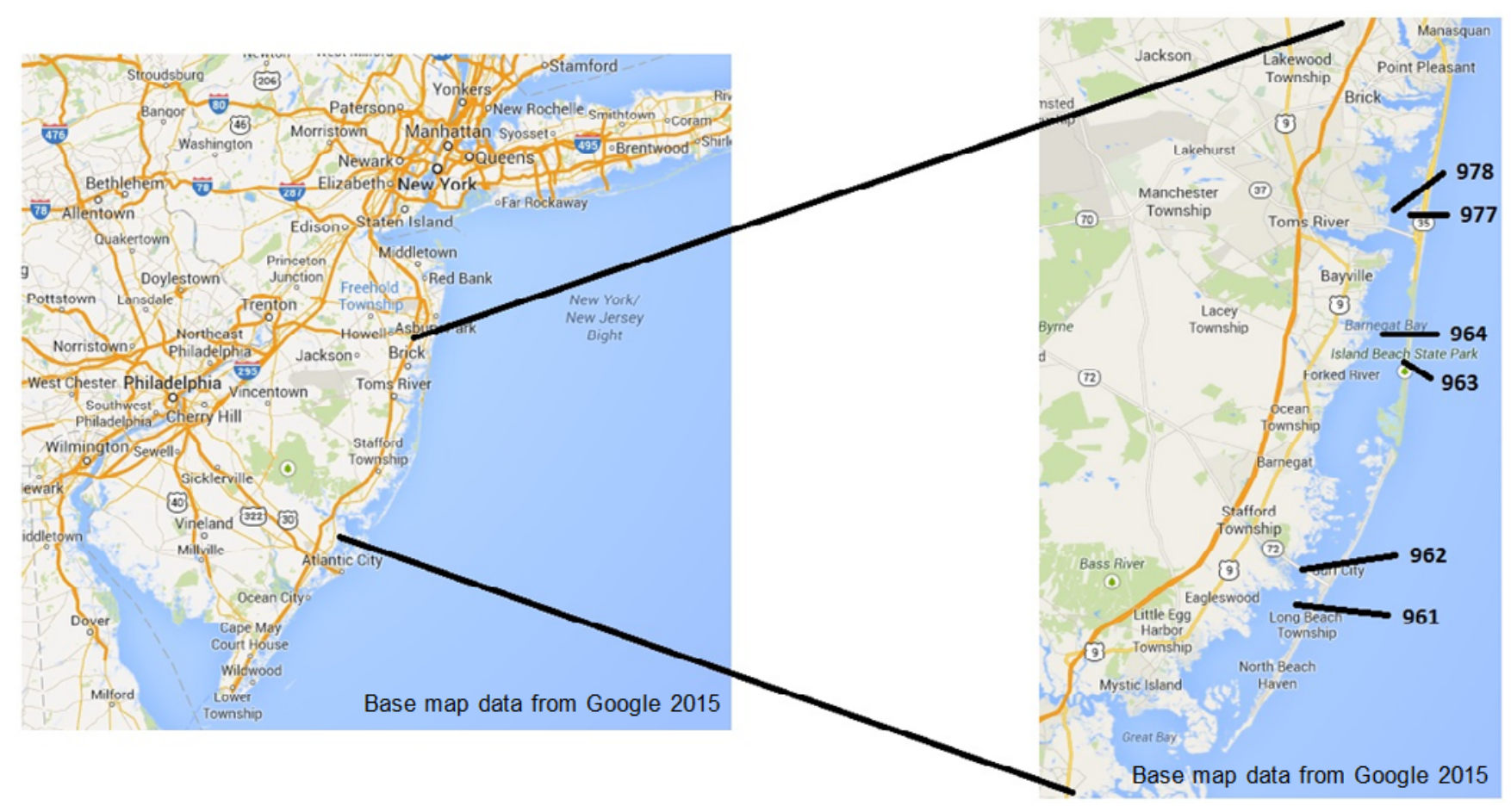

Figure 1. Maps showing sampling locations in the Barnegat Bay-Little Egg Harbor estuary, New Jersey. For site names, coordinates, sensor depth, and deployment periods, organized by the three-digit mooring identification numbers (IDs) shown, see table 1. For instrumentation information, sensor elevation, and associated data files, by mooring IDs, see table 2. 


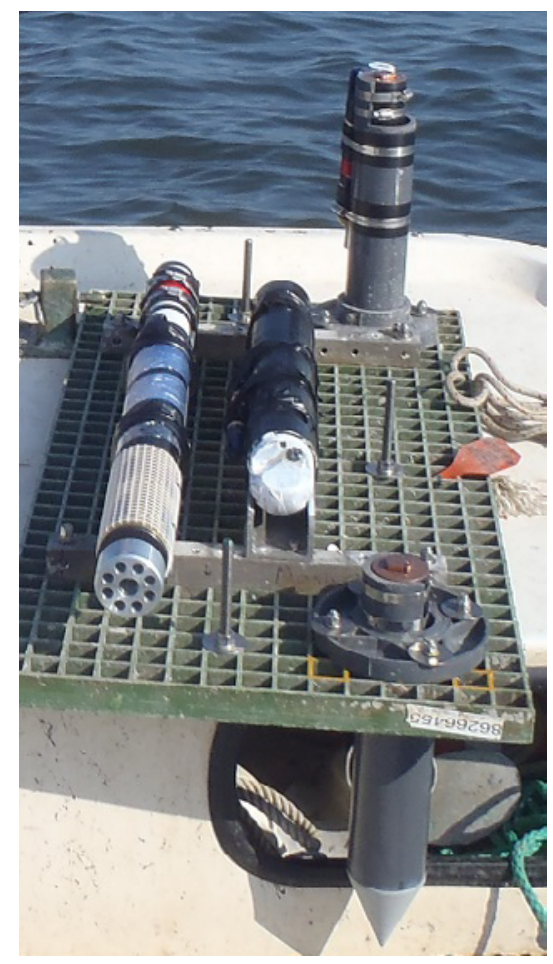

Figure 2. Photograph of the shallow water irradiance platform before deployment in the Barnegat Bay-Little Egg Harbor estuary, New Jersey. 


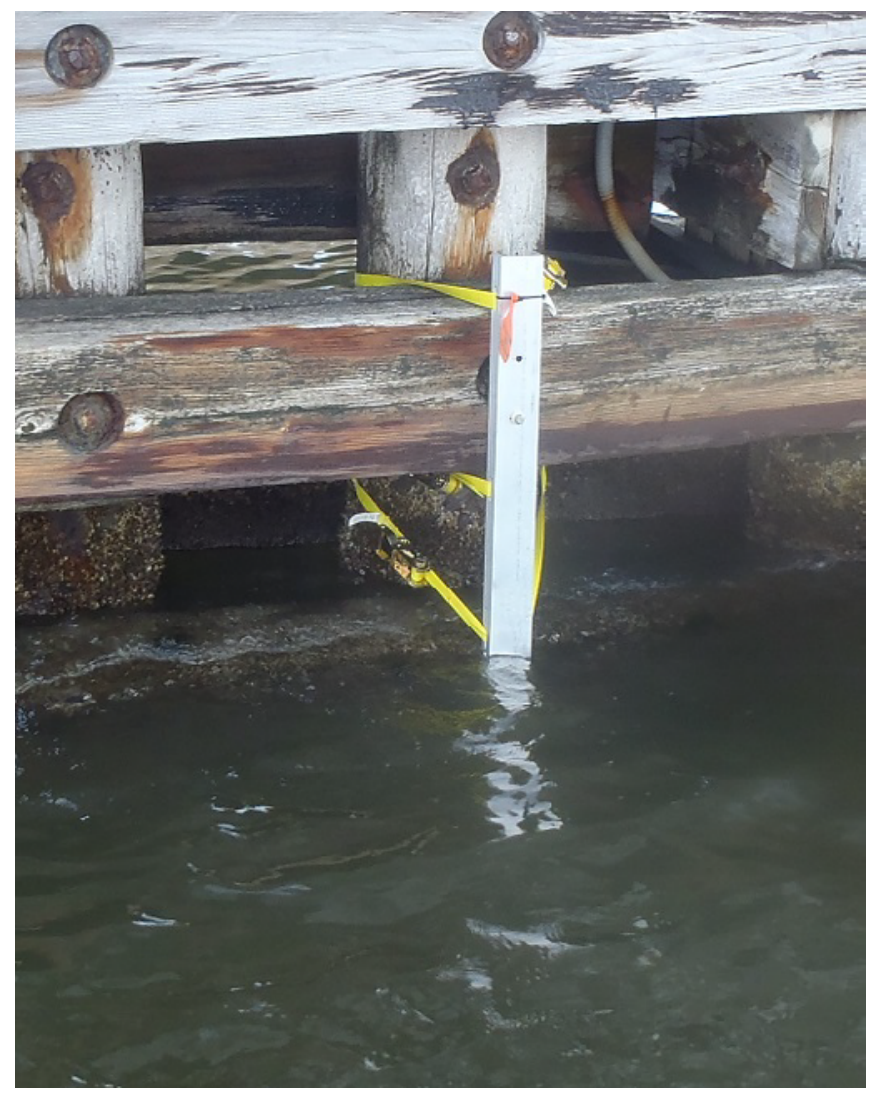

Figure 3. Photograph of pole-mounted sensors (just visible below the surface) after deployment on the State Route 72 bridge in the Barnegat Bay-Little Egg Harbor estuary, New Jersey. 


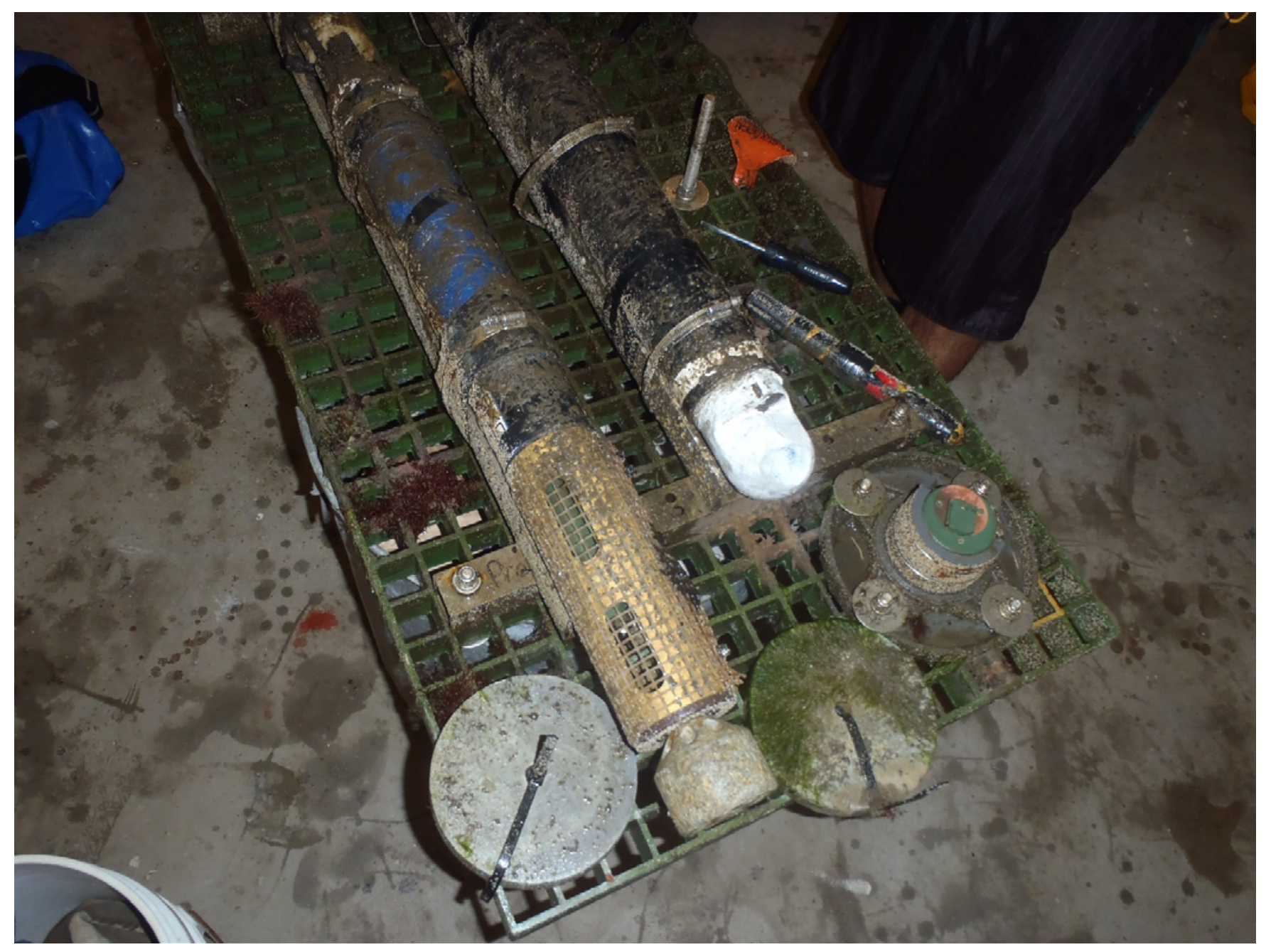

Figure 4. Photograph of biological fouling on the Tices Shoal shallow water irradiance platform after recovery from the Barnegat Bay-Little Egg Harbor estuary, New Jersey. 


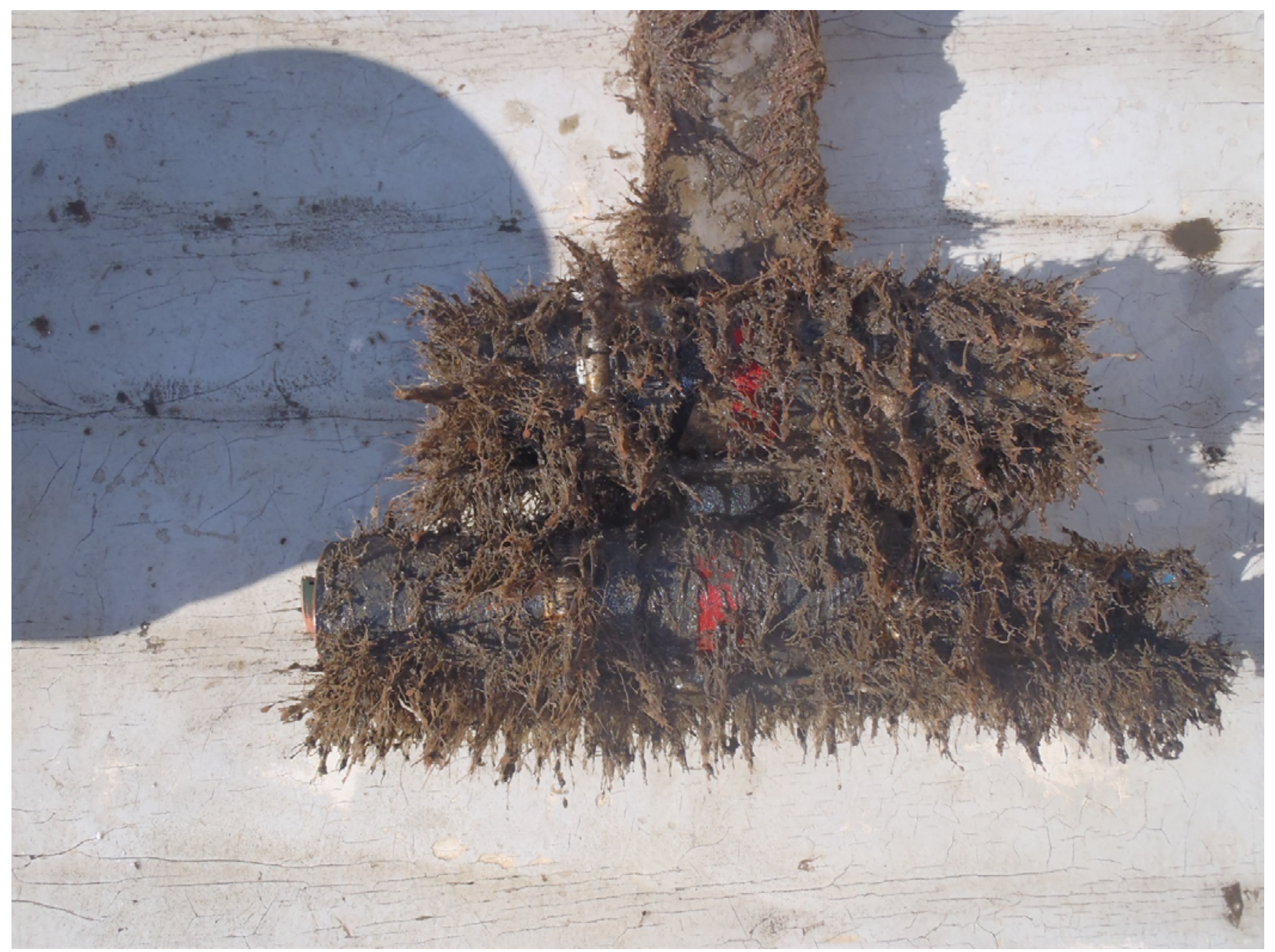

Figure 5. Photograph of fouling on the pole-mounted sensors after recovery from Tices Shoal channel in the Barnegat Bay-Little Egg Harbor estuary, New Jersey. 
Barnegat Bay data available by instrument during 2013

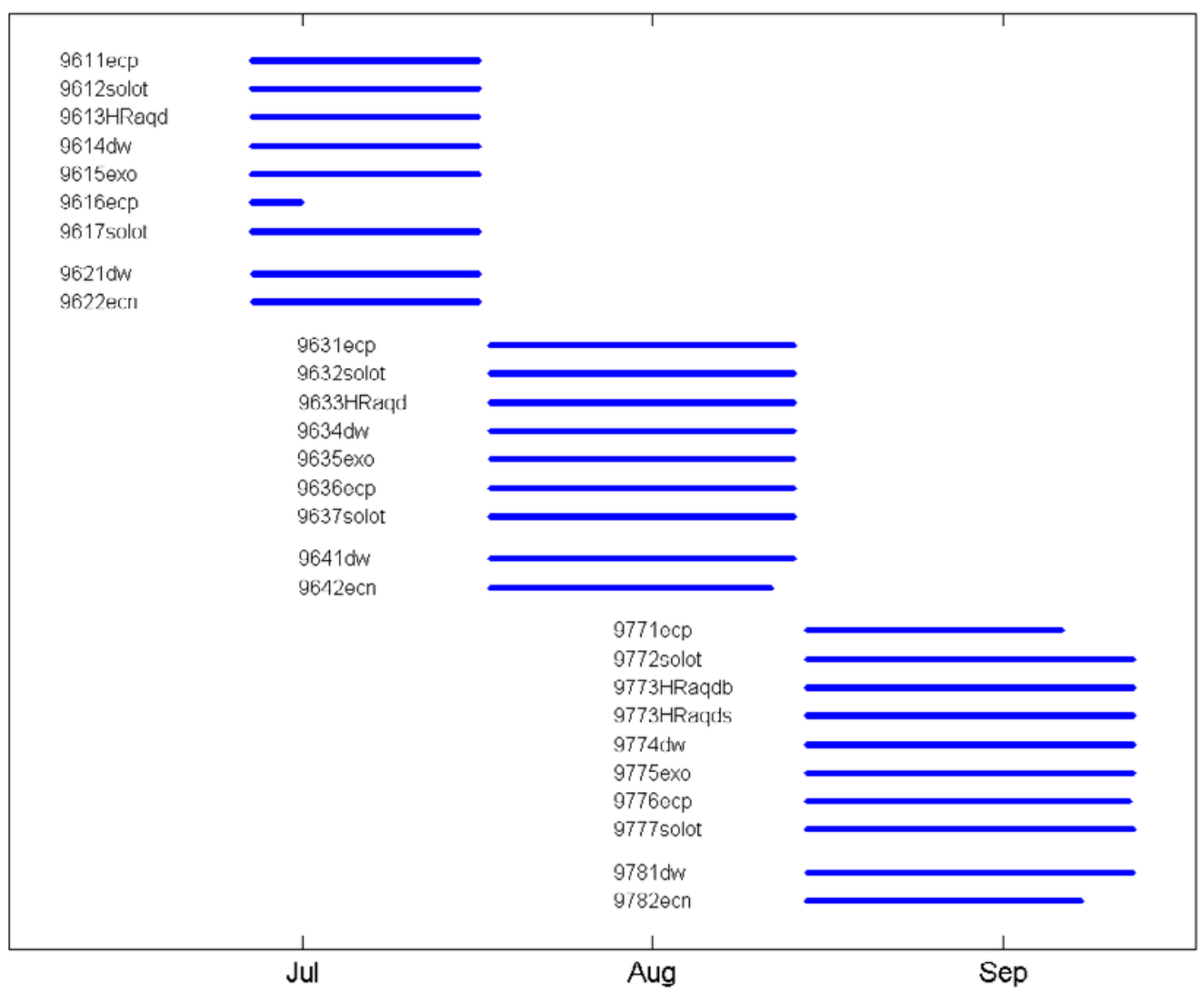

Figure 6. Chart showing the data available over time, by sensor and site, Barnegat Bay-Little Egg Harbor estuary, New Jersey. 

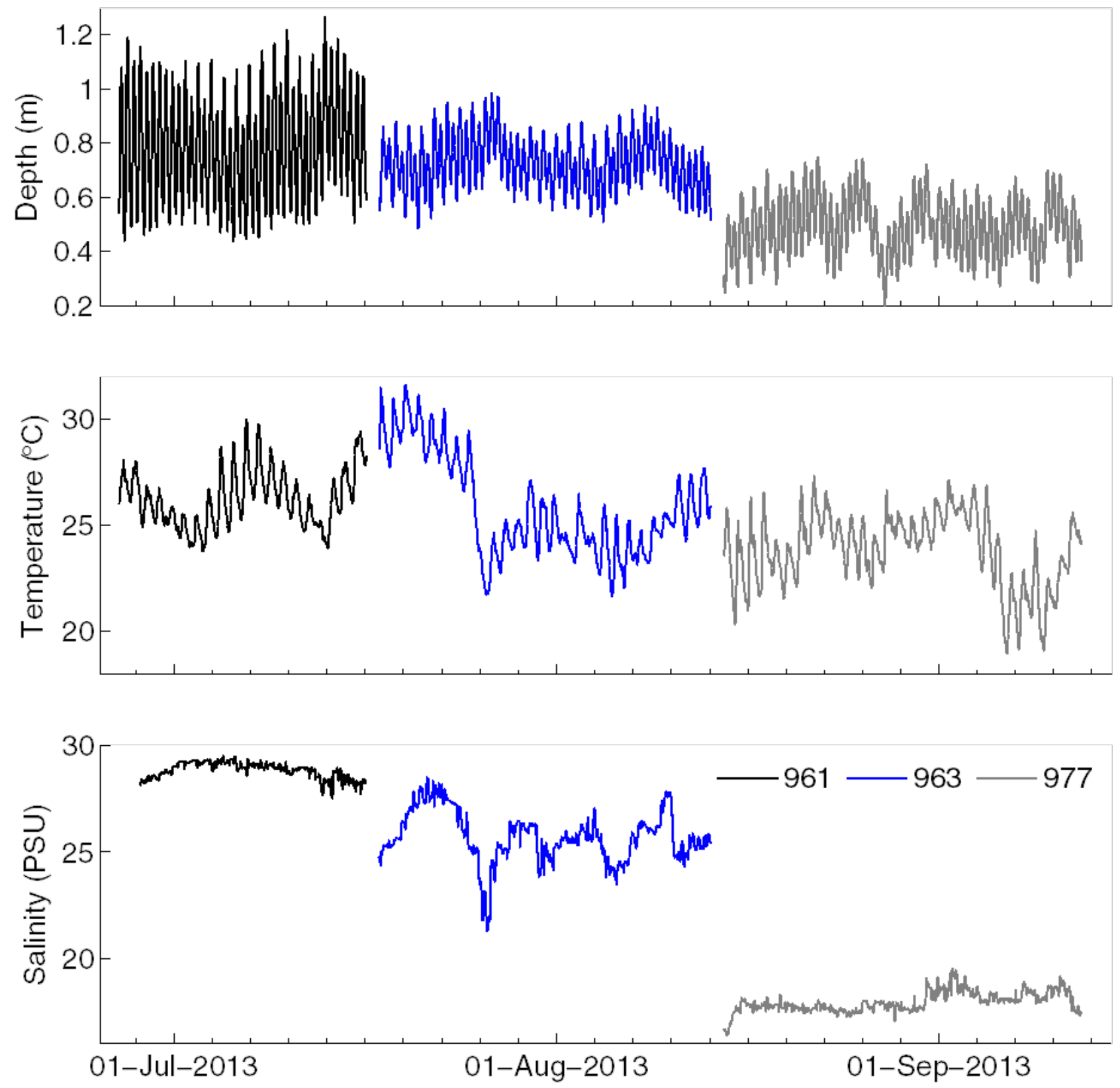

Figure 7. Graphs showing depth, temperature, and salinity time series from YSI EXO2 deployed at sites 961 (Little Egg Island shoal; black), 963 (Tices Shoal; blue), and 977 (shoal near Lavallette; gray), Barnegat Bay-Little Egg Harbor estuary, New Jersey. m, meter; ${ }^{\circ} \mathrm{C}$, degree Celsius; PSU, practical salinity unit. 

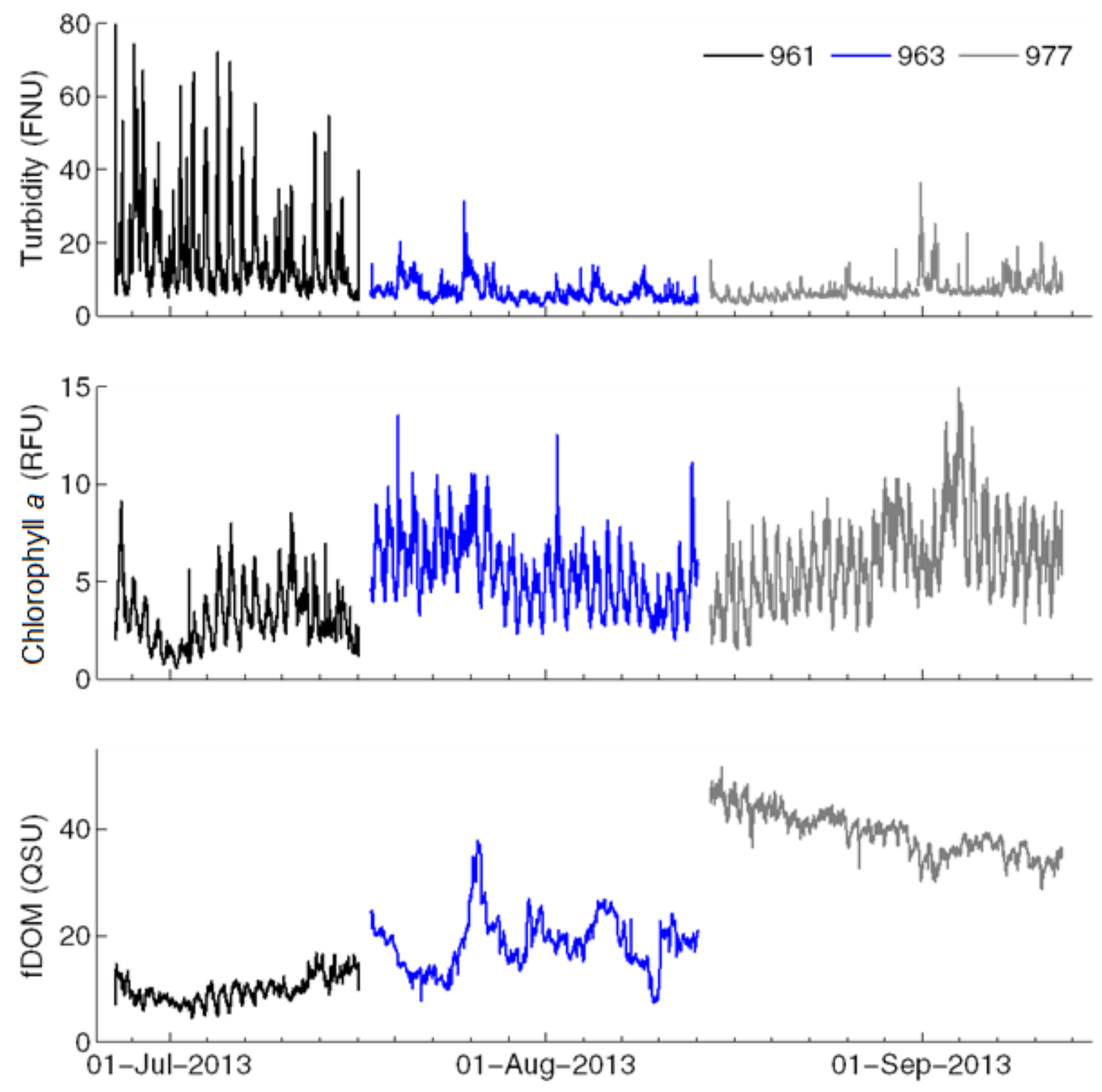

Figure 8. Graphs showing turbidity, chlorophyll a, and fluorescent dissolved organic matter (fDOM) time series from YSI EXO2 deployed at sites 961 (Little Egg Island shoal; black), 963 (Tices Shoal; blue), and 977 (shoal near Lavallette; gray), Barnegat Bay-Little Egg Harbor estuary, New Jersey. FNU, formazin nephelometric unit; RFU, relative fluorescence unit; QSU, quinine sulfate equivalent. 

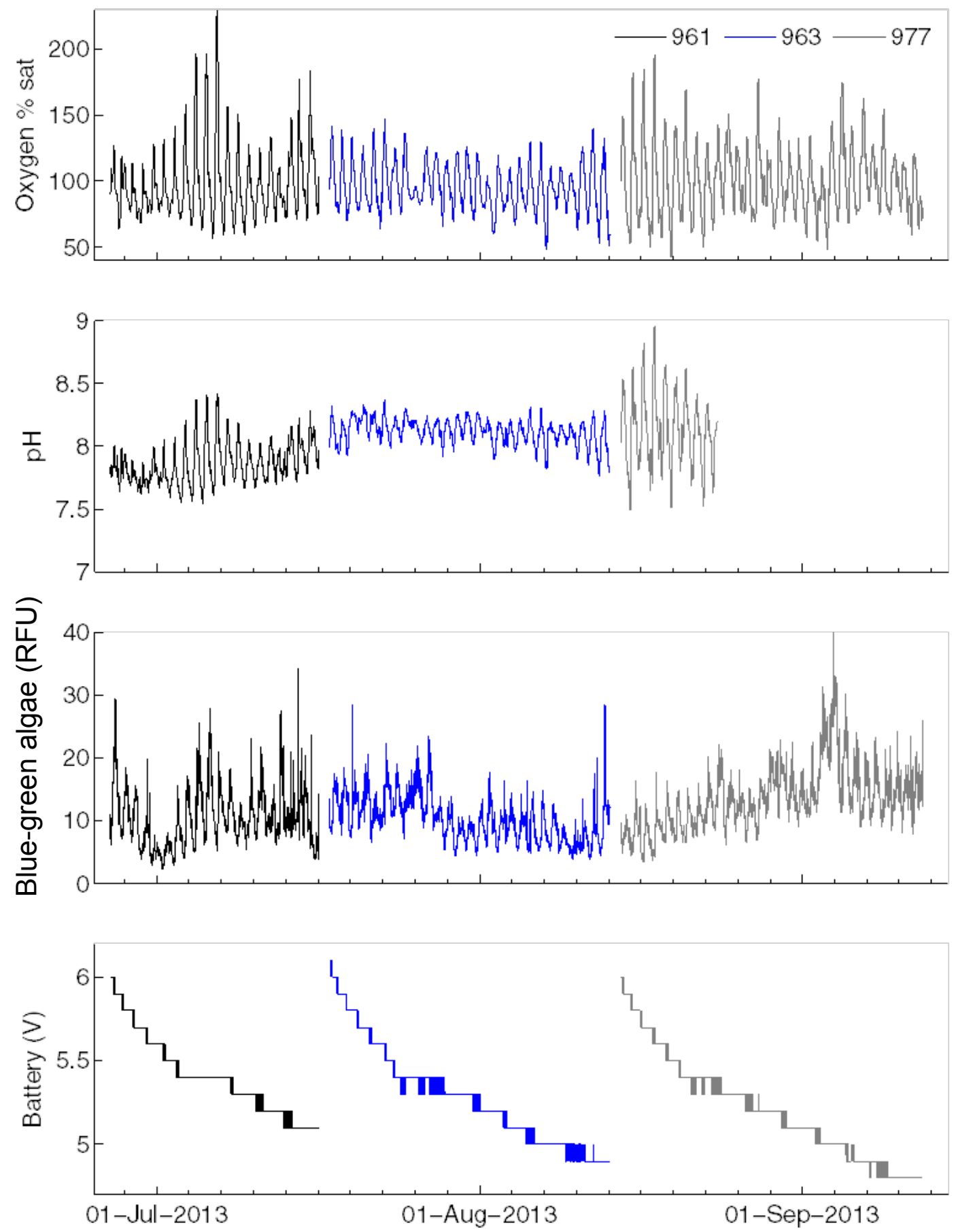

Figure 9. Graphs showing oxygen percent saturation, $\mathrm{pH}$, blue-green algae, and battery voltage time series from YSI EXO2 deployed at sites 961 (Little Egg Island shoal; black), 963 (Tices Shoal; blue), and 977 (shoal near Lavallette; gray), Barnegat Bay-Little Egg Harbor estuary, New Jersey. \% sat, percent saturation; RFU, relative fluorescence unit; $\mathrm{V}$, volt. 

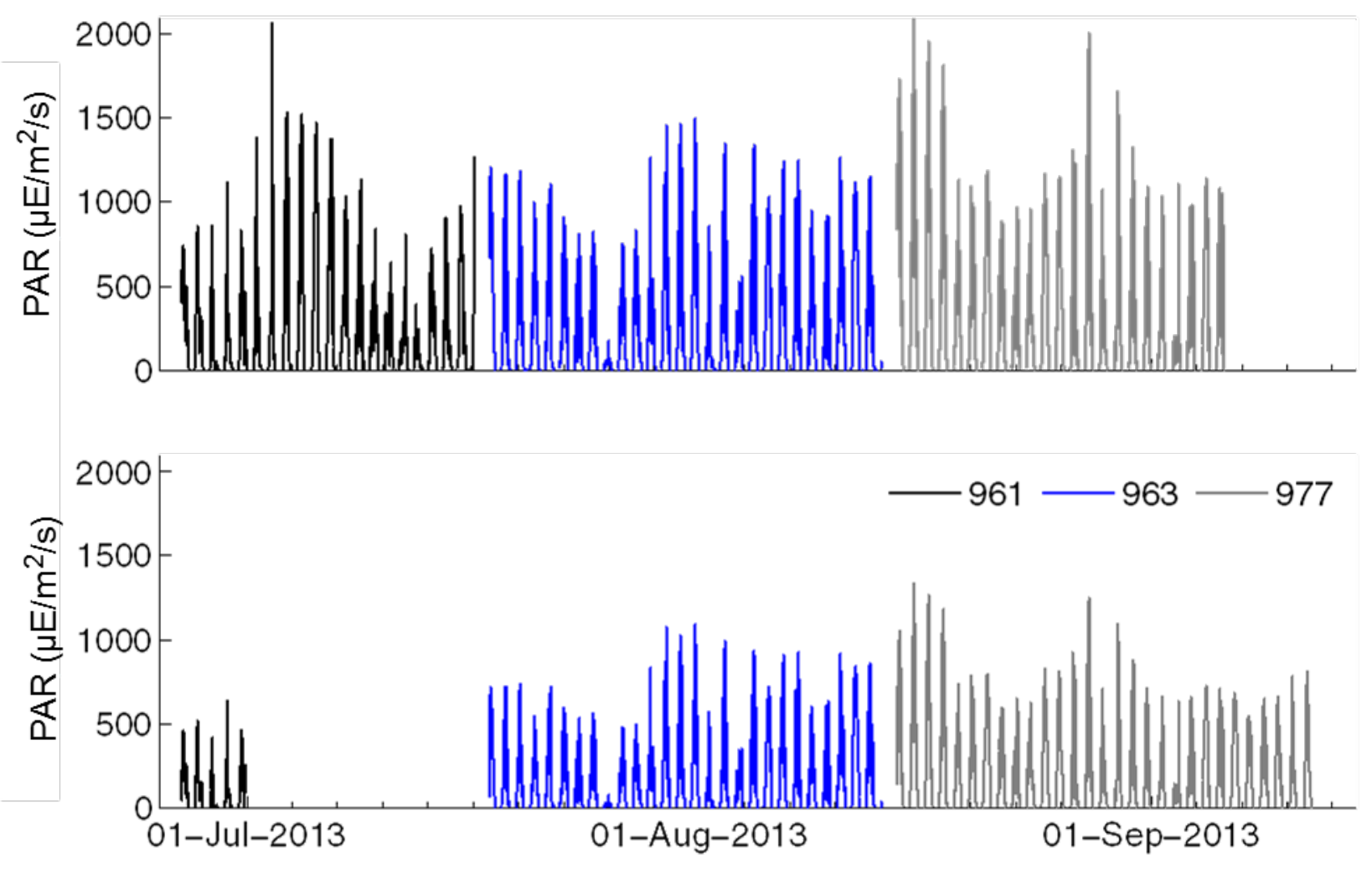

Figure 10. Graphs showing photosynthetically active radiation (PAR) time series from Wet Labs ECO-PARSB sensors mounted at 0.44 meters above bottom (mab; top panel) and 0.13 mab (bottom panel) and deployed at sites 961 (Little Egg Island shoal; black), 963 (Tices Shoal; blue), and 977 (shoal near Lavallette; gray), Barnegat Bay-Little Egg Harbor estuary, New Jersey. $\mu \mathrm{E} / \mathrm{m}^{2} / \mathrm{s}$, microEinstein per meter squared per second. 

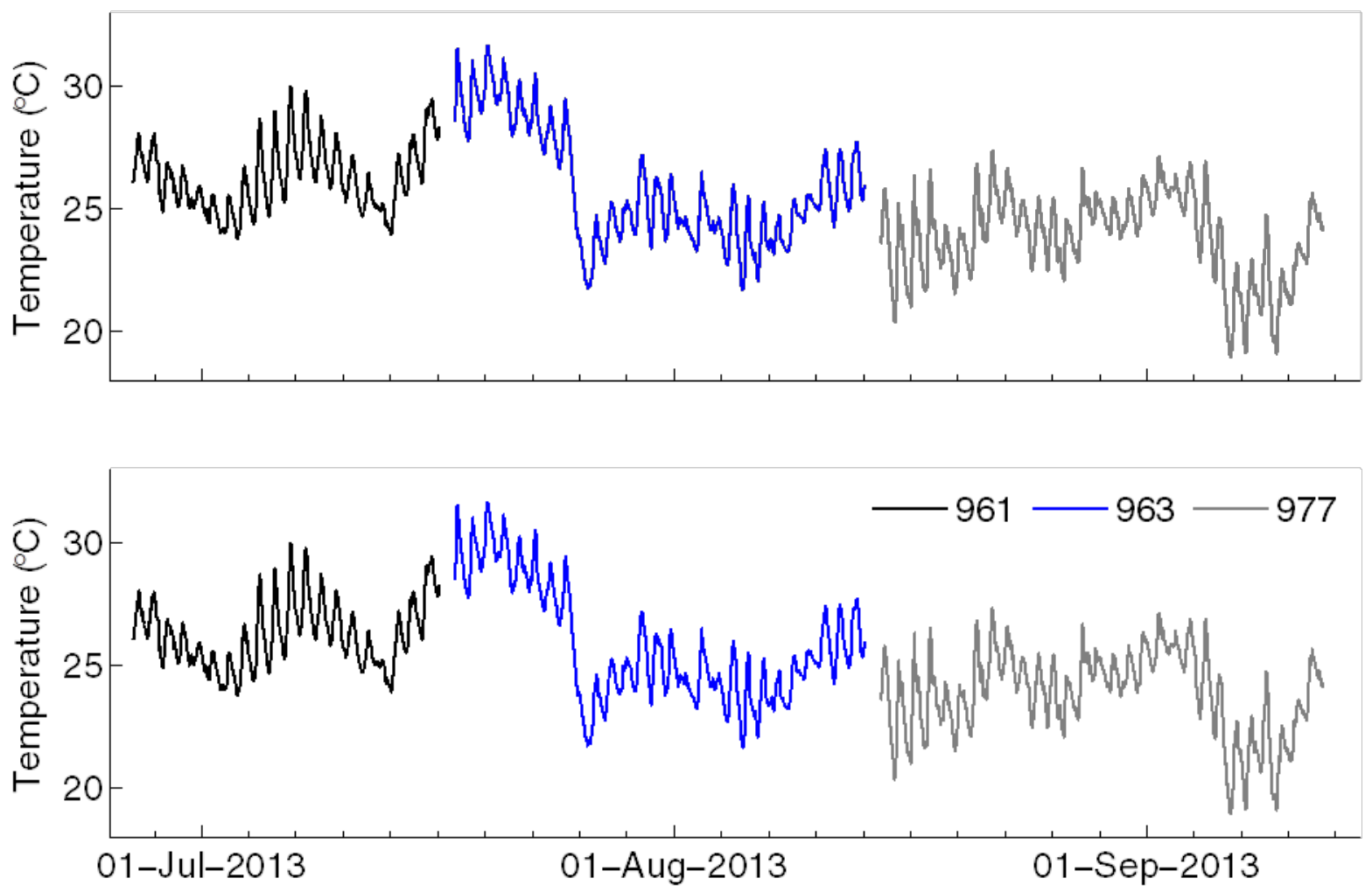

Figure 11. Graphs showing temperature time series from RBR Solo T mounted at 0.44 meters above bottom (mab; top panel) and 0.13 mab (bottom panel) and deployed at sites 961 (Little Egg Island shoal; black), 963 (Tices Shoal; blue), and 977 (shoal near Lavallette; gray), Barnegat Bay-Little Egg Harbor estuary, New Jersey. ${ }^{\circ} \mathrm{C}$, degree Celsius.

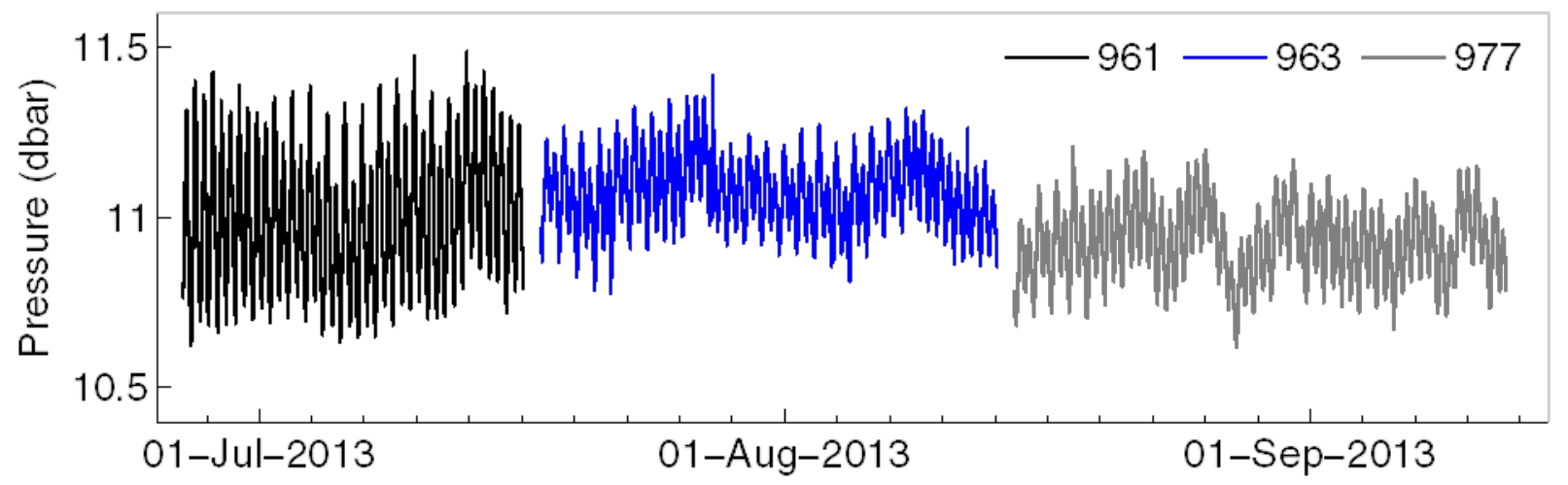

Figure 12. Graph showing pressure time series from RBR Virtuoso D|wave deployed at sites 961 (Little Egg Island shoal; black), 963 (Tices Shoal; blue), and 977 (shoal near Lavallette; gray), Barnegat Bay-Little Egg Harbor estuary, New Jersey. dbar, decibar. 

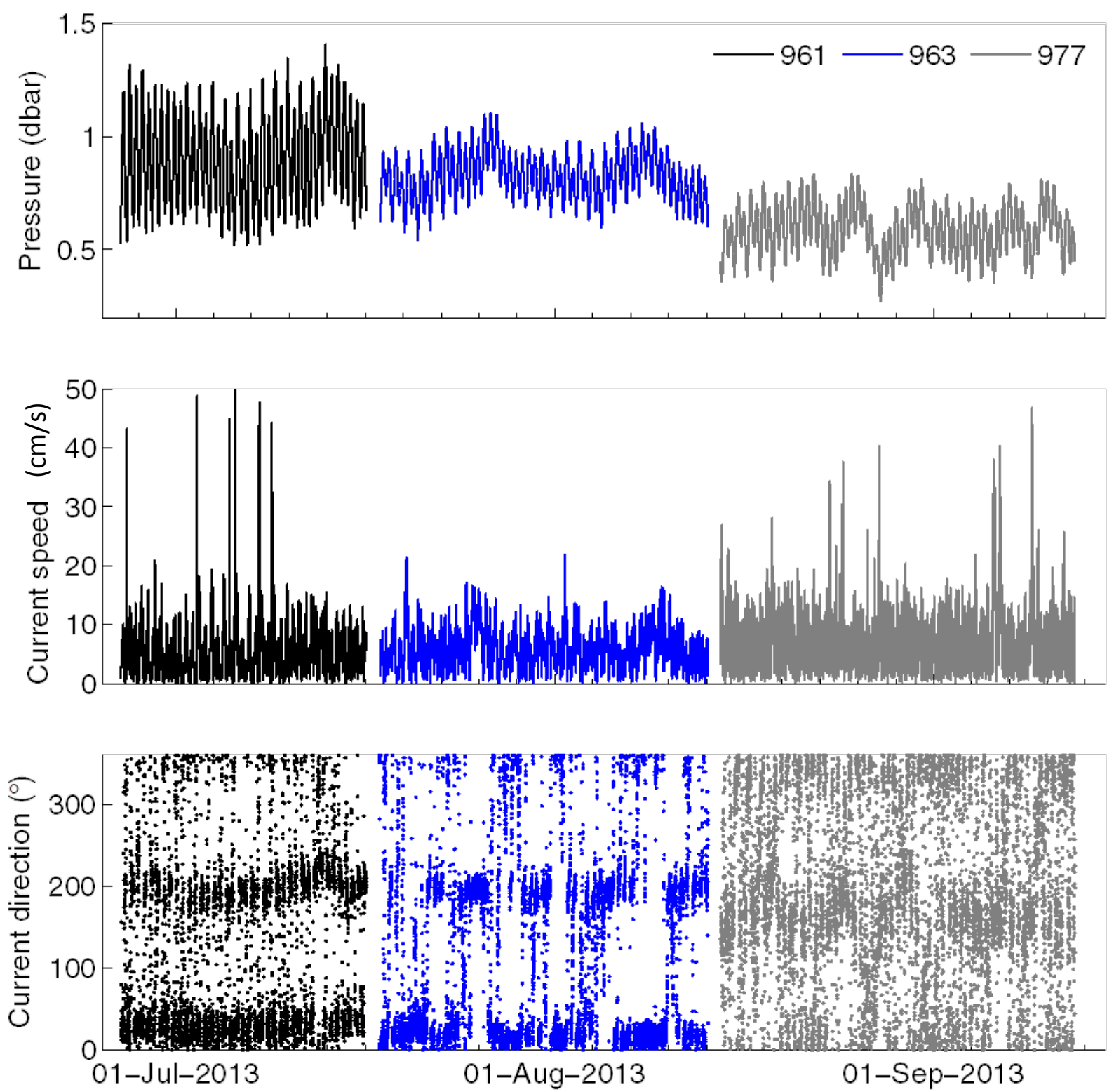

Figure 13. Graphs showing pressure, current speed, and current direction time series from Nortek Aquadopp HR deployed at sites 961 (Little Egg Island shoal; black), 963 (Tices Shoal; blue), and 977 (shoal near Lavallette; gray), Barnegat Bay-Little Egg Harbor estuary, New Jersey. dbar, decibar; $\mathrm{cm} / \mathrm{s}$, centimeter per second; ${ }^{\circ}$, degree. 

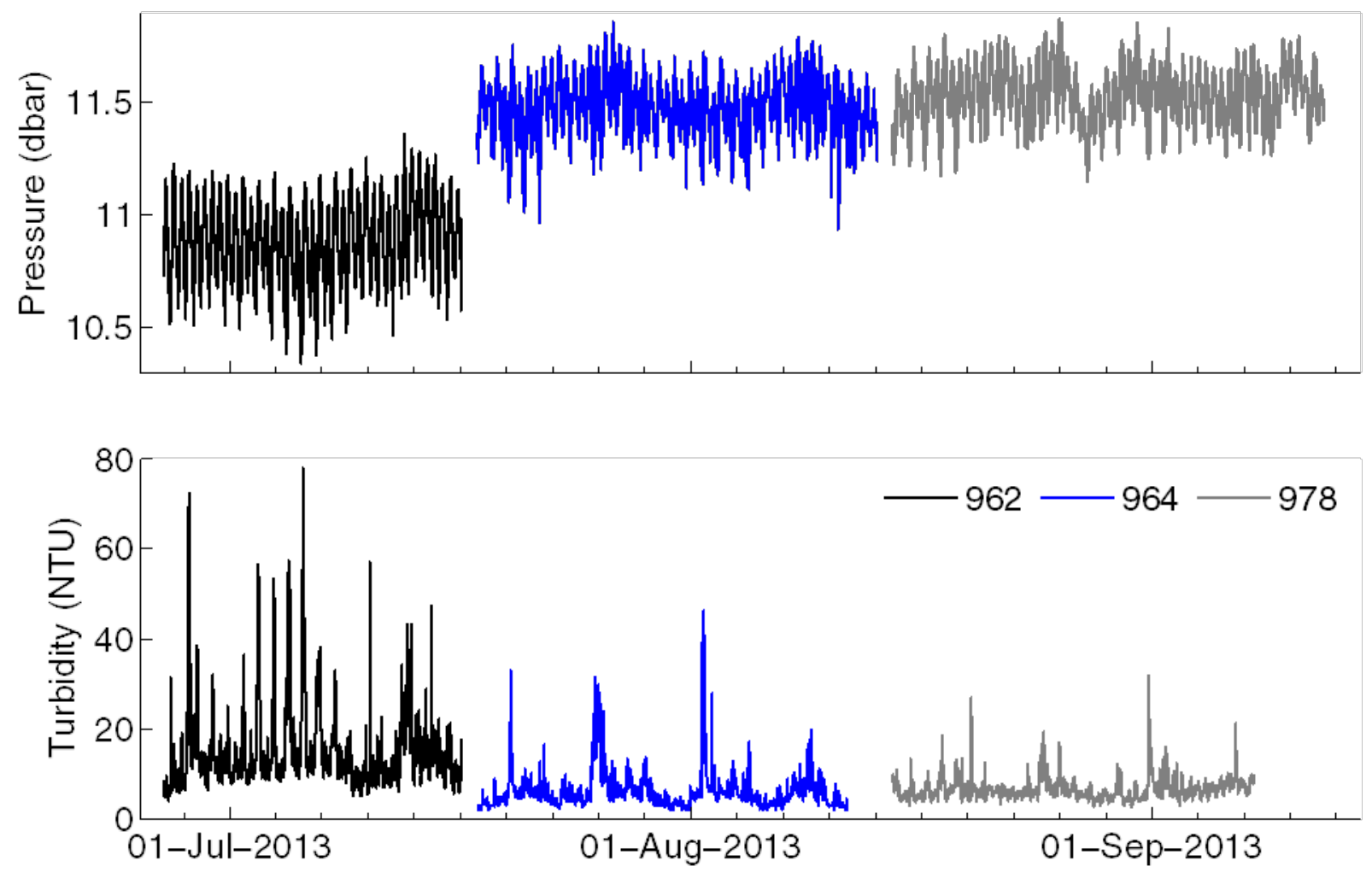

Figure 14. Graphs showing pressure time series from RBR Virtuoso D/wave and turbidity time series from Wet Labs ECO-NTUSB deployed at sites 962 (channel at State Route 72 bridge; black), 964 (channel near Tices Shoal; blue), and 978 (channel near Lavallette; gray), Barnegat Bay-Little Egg Harbor estuary, New Jersey. dbar, decibar; NTU, nephelometric turbidity unit. 
For more information concerning this report, contact:

Director, Woods Hole Coastal and Marine Science Center

U.S. Geological Survey

384 Woods Hole Road

Quissett Campus

Woods Hole, MA 02543-1598

WHSC_science_director@usgs.gov

508-548-8700 or 508-457-2200

or visit our Web site at:

http://woodshole.er.usgs.gov/

Publishing support by:

The Pembroke Publishing Service Center. 
